\title{
Pelaksanaan Rapid Test Antigen Covid-19 Kepada Generasi Muda Kota Medan dan Deli Serdang
}

\author{
https://doi.org/10.32509/abdimoestopo.v4i02.1447
}

\author{
Lenny Lusia Simatupang1, Harsudianto Silaen ${ }^{2 *}$, Seriga Banjarnahor ${ }^{3}$, \\ Regina Marintan Sinaga ${ }^{4}$ \\ 1,2,3 Program Studi Ilmu Keperawatan STIKes Murni Teguh \\ ${ }^{4}$ Program Studi D-III Kebidanan STIKes Murni Teguh \\ Jl. Jawa No. 2, Medan, Sumatera Utara, Indonesia \\ *Email Korespondensi : antosilaen4@gmail.com
}

\begin{abstract}
This community service is carried out in line with the increase in the number of Covid-19 cases taking place quite quickly and there has been a spread between countries. Based on scientific evidence, Covid-19 can be transmitted from human to human through droplets. People who are most at risk of contracting this disease are people who have close contact with Covid-19 patients, including those who treat Covid-19 patients. The method used in this activity uses several stages, namely 1) Registration, 2) Health screening, 3) Explanation (informed consent), neat test with antigen, 4) Evaluation of results and the final stage, 5) Notification of the results of the Covid-19 Antigen Test. The participants of the Covid-19 Antigen Rapid Test were 100 people. The results of community service to the implementation of the Covid-19 Antigen Rapid Test to 100 people showed that 99 people obtained the Non-Reactive (-) result and 1 person was the Reactive (+) Covid-19 result. It is suggested that every activity of the Young Generation of the City of Medan and Deli Serdang is expected during the Covid19 pandemic to carry out a Rapid Test to detect early so that in carrying out activities it does not cause transmission.
\end{abstract}

Keywords: Rapid Test, Young Generation, Covid-19

Abstrak - Pengabdian masyarakat ini dilakukan seiring dengan penambahan jumlah kasus Covid-19 berlangsung cukup cepat dan sudah terjadi penyebaran antar negara. Berdasarkan bukti ilmiah, Covid-19 dapat menular dari manusia ke manusia melalui percikan batuk/bersin (droplet). Orang yang paling berisiko tertular penyakit ini adalah orang yang kontak erat dengan pasien Covid-19 termasuk yang merawat pasien Covid-19. Metode yang digunakan dalam kegiatan ini menggunakan beberapa tahap yaitu 1) Pendaftaran, 2) Skrinning kesehatan, 3) Penjelasan (informed consent) rapit test dengan antigen, 4) Evaluasi hasil serta tahap akhir, 5) Pemberitahuan hasil Test Antigen Covid-19. Peserta Rapid Test Antigen Covid-19 sebanyak 100 orang. Hasil pengabdian masyarakat terhadap pelaksanaan Rapid Test Antigen Covid-19 kepada 100 orang bahwa 99 orang memperoleh hasil Non Reaktif (-) dan 1 orang hasil Reaktif (+) Covid-19. Saran bahwa setiap kegiatan Generasi Muda Kota Medan dan Deli Serdang diharapkan selama pandemi Covid-19 melakukan testing Rapid Test untuk mendeteksi awal sehingga dalam pelaksanaan kegiatan tidak menyebabkan penularan.

Kata Kunci: Rapid Test, Generasi Muda, Covid-19

\section{PENDAHULUAN}

Penambahan jumlah kasus Covid-19 berlangsung cukup cepat dan sudah terjadi penyebaran antar negara. Sampai dengan tanggal 25 Maret 2020, dilaporkan total kasus konfirmasi 414.179 dengan 18.440 kematian (CFR 4,4\%) dimana kasus dilaporkan di 192 negara/wilayah. Diantara kasus tersebut, sudah ada beberapa petugas kesehatan yang 
dilaporkan terinfeksi. Pada tanggal 2 Maret 2020, Indonesia melaporkan kasus konfirmasi Covid-19 sebanyak 2 kasus. Sampai dengan tanggal 25 Maret 2020, Indonesia sudah melaporkan 790 kasus konfirmasi Covid-19 dari 24 Provinsi yaitu: Bali, Banten, DIY, DKI Jakarta, Jambi, Jawa Barat, Jawa Tengah, Jawa Timur, Kalimantan Barat, Kalimantan Timur, Kalimantan Tengah, Kalimantan Selatan, Kep. Riau, Nusa Tenggara Barat, Sumatera Selatan, Sumatera Utara, Sulawesi Utara, Sulawesi Tenggara, Sulawesi Selatan, Lampung, Riau, Maluku Utara, Maluku dan Papua. Wilayah dengan transmisi lokal di Indonesia adalah DKI Jakarta, Banten (Kab. Tangerang, Kota Tangerang), Jawa Barat (Kota Bandung, Kab. Bekasi, Kota Bekasi, Kota Depok, Kab. Bogor, Kab. Bogor, Kab. Karawang), Jawa Timur (kab. Malang, Kab. Magetan dan Kota Surabaya) dan Jawa Tengah (Kota Surakarta). Hasil laporan dari Gugus Tugas Covid-19 Pemerintah Provinsi Sumatera Utara tanggal 14 Mei 2021 bahwa Kabupaten Deli Serdang kasus terkonfirmasi sebanyak 4615 orang, Kota Medan terkonfirmasi sebanyak 15834 orang dan Total terkonfimasi di Provinsi Sumatera Utara sebanyak 30390 orang (Kemenkes, 2020).

Berdasarkan bukti ilmiah, Covid-19 dapat menular dari manusia ke manusia melalui percikan batuk/bersin (droplet). Orang yang paling berisiko tertular penyakit ini adalah orang yang kontak erat dengan pasien Covid-19 termasuk yang merawat pasien Covid-19. Rekomendasi standar untuk mencegah penyebaran infeksi adalah melalui cuci tangan secara teratur menggunakan sabun dan air bersih, menerapkan etika batuk dan bersin, menghindari kontak secara langsung dengan ternak dan hewan liar serta menghindari kontak dekat dengan siapapun yang menunjukkan gejala penyakit pernapasan seperti batuk dan bersin. Selain itu, menerapkan Pencegahan dan Pengendalian Infeksi (PPI) saat berada di fasilitas kesehatan terutama unit gawat darurat (Kemenkes, 2020).

Penggunaan alat tracing (pelacakan) standar yang ditetapkan World Health Organization (WHO) dalam testing dan tracing di Indonesia masih terbatas. Indikator pengendalian pandemi dilakukan dengan tracing, testing dan treatment. Testing sangat kurang dan tracing juga sangat kurang. Pelaksanaan testing atau pemeriksaan Covid-19 dilakukan sebanyak-banyaknya. Hasil testing yang menunjukkan kasus positif Covid-19. Sebab kondisi tersebut justru dapat mendeteksi pergerakan mutasi varian baru virus corona. Dari hasil tracing 15 kontak erat dalam waktu 72 jam dan testing kalau bisa dilalukan sebanyak-banyaknya. WHO telah memberikan pedoman bahwa untuk setiap unit terkecil harus minimal 1 per 1000 orang ditesting per minggu. Jika jumlah seluruh penduduk Indonesia sekitar 270.000, maka dalam sehari setidaknya ada 40.000 orang diperiksa. Dalam sepekan, idealnya ada 280.000 orang yang diperiksa (Kemenkes, 2020).

Negara Indonesia sendiri, ada tiga jenis prosedur medis yang bisa digunakan untuk mengidentifikasi penyakit Covid-19, yaitu rapid tes antibodi, rapid tes antigen, dan PCR. Dibandingkan dengan rapid tes, PCR memang menjadi metode pemeriksaan yang memiliki tingkat akurasi tertinggi. Namun, dibandingkan rapid tes antibodi, rapid tes antigen masih lebih baik. Negara Indonesia pemeriksaan rapid test antibody digunakan sebagai pemeriksaan skrining adanya antibodi terhadap Covid-19 misalnya pada pelaku perjalanan lintas batas, dan penguatan pelacakan kontak seperti di lapas, pondok pesantren, dan lain-lain (Kemenkes, 2020).

Sampai saat ini belum ditemukan terapi yang tepat untuk mengatasi Covid-19, sehingga langkah-langkah preventif sangat penting dilakukan. Kebijakan pemerintah berupa pembatasan sosial tidak akan efektif tanpa dukungan pemberian informasi dan edukasi pada masyarakat. Maraknya disinformasi di masyarakat dapat menimbulkan kekhawatiran, serta mendorong pada pengambilan langkah-langkah pencegahan yang tidak berdasarkan bukti ilmiah. Pemberian informasi dan edukasi kepada masyarakat perlu dilaksanakan secara rutin. Pengetahuan dan sikap seseorang tentang pandemi ini memainkan peranan penting dalam mengembangkan perilaku yang sesuai dengan protokol kesehatan (Azlan,dkk, 2020). 
Beberapa langkah antisipasi dilakukan Pemerintah Indonesia dimulai dari kebijakan WFH (Work from Home), pembelajaran melalui media daring hingga penetapan status PSBB di beberapa daerah yang dinyatakan sebagai zona merah penyebaran Covid-19. Tujuannya adalah mencegah terjadinya kerumunan atau pengumpulan masa untuk mengurangi atau mencegah penyebaran Covid-19 dari satu manusia ke manusia yang lain(Telaumbanua, 2020). Seperti empat stategi pemerintah yang disampaikan Gugus Tugas Percepatan Penanganan Covid-19 untuk menguatkan kebijakan physical distancing sebagai strategi dasar demi mengatasi penyebaran Covid-19 yaitu gerakan masker dengan mewajibkan siapa saja menggunakan masker bila beraktifitas di ruang publik, strategi kedua penelusuran kontak (tracing) dari kasus positif, strategi ketiga edukasi dan penyiapan isolasi secara mandiri pada sebagian hasil tracing yang menunjukkan hasi positif dan strategi yang terakhir isolasi rumah sakit yang dilakukan kala isolasi mandiri tidak mungkin dilakukan (Wibowo, 2020).

Dari keempat strategi tersebut, hal yang agak sulit dilakukan adalah penelusuran kontak (tracing) dari kasus positif apalagi bila kasus tersebut adalah OTG (Orang Tanpa Gejala). Melacak siapa saja yang pernah kontak dengan penderita bila dilakukan secara manual memerlukan waktu yang cukup lama dan dalam rentang waktu tersebut bisa saja sudah terjadi penyebaran virus yang sangat cepat. Dan untuk menangani hal tersebut diperlukan bantuan teknologi berupa aplikasi yang dapat men-tracing riwayat perjalanan kita, salah satunya adalah aplikasi yang diluncurkan pemerintah melalui Kementerian Komunikasi dan Informatika (Kominfo). Aplikasi ini cukup lama diluncurkan oleh pemerintah, namun hanya sebagian yang memahami atau mengetahui aplikasi PeduliLindungi yang sangat bermanfaat untuk penelusuran kontak (tracing) dari kasus positif (Wibowo, 2020).

STIKes Murni teguh sebagai salah satu lembaga pendidikan tinggi yang berkewajiban menyelenggarakan Tridharma Perguruan Tinggi yaitu Pendidikan, Penelitan dan Pengabdian kepada masyarakat. Dengan adanya pandemik Covid-19 yang terjadi di seluruh negara termasuk salah satunya adalah Negara Indonesia, maka salah satu kegiatan untuk mencegah penularan Covid-19 dengan adanya deteksi dini penyebaran Covid-19 dengan Antigen.

\section{METODE PELAKSANAAN}

Pada kesempatan ini kami dosen kesehatan ingin melakukan kontribusi di masa pandemi Covid-19 yaitu melakukan pengbadian masyarakat, dimana bentuk pengabdian yang membantu serta mencegah terjadi terjadinya penularan dan menekan angka kejadian Covid-19. Prinsip dari pada pelaksanaan kegiatan ini merupakan kegiatan persiapan anak muda Kota Medan dan Deli Serdang untuk lebih peduli terhadap lingkungan dan kegiatan sehari-hari. Guna mendukung kegiatan/acara Generasi Muda Kota Medan dan Deli Serdang di masa pandemi, acara tersebut harus dipertimbangkan dengan baik dalam pelaksanaannya di masa pandemi Covid-19. Sebelum melakukan kegiatan/acara, panitia harus melakukan persiapan guna melakukan pengecekan serta kesiapan untuk melaksanakan kegiatan. Pada kesempatan ini pantia berjumlah sebanyak 100 orang dan akan dilakukan tracing (pelacakan) dan testing (memeriksa) apakah ada yang terkonfirmasi Covid-19. Kegiatan pencegahan penularan Covid19 yaitu pelaksanaan Rapit Test Antigen Covid-19 pada masyarakat di Kota Medan Dan Kabupaten Deli Serdang dilaksanakan pada tanggal 30 April 2021 s/d 01 Mei 2021. Kegiatan ini dihadiri oleh 100 peserta (panitia dan anggota) Generasi Kota Medan. Adapun kegiatan yang dilakukan beberapa tahap yaitu :

1) Pendaftaran : petugas melakukan pendaftaran berupa mengindentifikasi biodata serta melakukan wawancara khusus terkait kegiatan diluar rumah dan pernah kontak erat kepada pasien terkonfirmasi Covid-19,

2) Skrinning kesehatan : dilakukan skrinning kesehatan yaitu pemeriksaaan suhu tubuh dan wajib melakukan cuci tangan sebelum dilakukan swab, 
3) Penjelasan (informed consent) rapit test dengan antigen : petugas akan menjelaskan jenis alat yang akan digunakan, pada bagian mana yang akan diambil swab nya serta hasilnya keluar berapa lama,

4) Pengambilan sampel swab : akan dilakukan swab di daerah hidung atau mulut (jika hidungnya mengalami gangguan/nyeri), hasilnya akan di buat ke media/bagian alat swab dan dicampur dengan bahan sediaan.

5) Evaluasi hasil serta tahap akhir : setelah dilakukan pencampuran bahan swab dan cairan swab, maka peserta swab akan dapat melihat hasilnya, apakah reaktif atau tidak. Jika reaktif (positif) maka akan muncul 2 (dua) garis merah/pink, tetapi jika non reaktif garis merah/pink 1 (satu) maka hasilnya dikatakan negatif.

6) Pemberitahuan hasil Test Antigen Covid-19. : dari 100 orang dilakukan tracer dan testing maka kami memperoleh hasil bahwa 1 orang dikatakan reaktif (positif) terkonfirmasi Covid19 dan kami mengajurkan untuk melaporkan ke layanan kesehatan (puskemas) dan memfasilitasinya serta memberikan edukasi untuk isolasi mandiri.

\section{HASIL DAN PEMBAHASAN}

Hasil pengabdian masyarakat yang telah dilakukan tentang pencegahan penularan Covid-19 dapat dilihat dari hasil pemeriksaan Rapid Test Antigen selama 2 (Dua) hari kepada 100 orang peserta didapatkan 99 negatif dan 1 orang positif. Berikut merupakan tahap pelaksanaan Rapid Test Antigen : 1) Pendaftaran, 2) Skrinning kesehatan, 3) Penjelasan (informed consent) rapit test dengan antigen, 4) Evaluasi hasil serta tahap akhir, 5) Pemberitahuan hasil Test Antigen Covid-19.

Pada tahap ini yaitu tahap pendaftaran, sebelum dilakukan pengisian formulis, petugas melakukan edukasi dan konseling singkat terntang prosedur serta memberikan edukasi terkait Covid-19. Petugas mengarahkan peserta rapid test untuk mengisi formulir berisi biodata lengkap nama, alamat, dan lainnya. Selain biodata lengkap, formulir berupa daftar riwayat perjalanan termasuk kontak erat dengan pasien positif Covid-19 juga wajib diisi. Adapula pertanyaan apakah selama sepekan ada riwayat perjalanan ke dan dari zona rawan atau zona merah. Dalam proses pengisian formulir petugas melakukan konseling singkat tentang Covid19 penerapan masker, jaga jarak, menghindari kerumunan, mencuci tangan sering dan keluar rumah jikalau perlu. Hal ini perkuat bahwa perlu dilakukan konseling terhadap masyarakat untuk mencegah penyakit termasuk Covid-19 (Silaen, 2019).

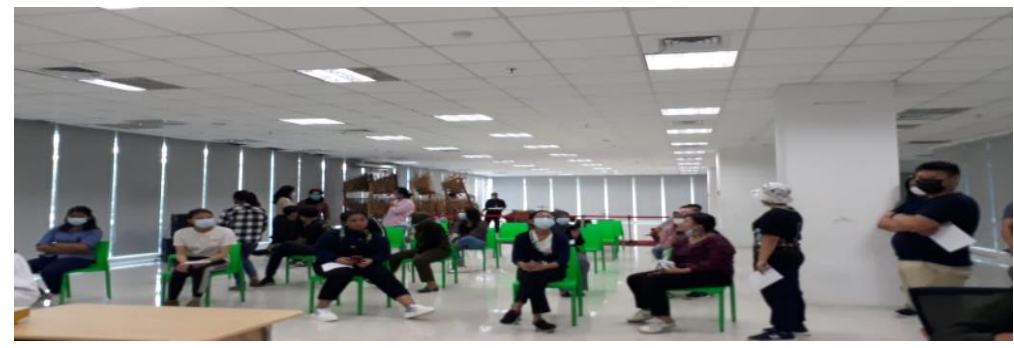

Gambar 1. Pendaftaran Rapit Test

Pada tahap skrinning petugas melakukan pemeriksaan tanda-tanda atau keluhan umum yang dirasakan pasien, apakah ada batuk, demam naik turun, flu yang tidak sembuh serta bertanya tentang apakah ada riwayat kontak dengan pasien Covid-19. Pada kesempatan ini juga kami menggali pengetahuan pasien tentang penularan Covid-19 dan pentingnya dilakukan pemeriksaan berkala untuk pelaku perjalanan dan pelaku usaha. Hasil ini diperkuat bahwa jika ada riwayat kontak dengan pasien Covid-19 serta tidak menjaga jarak maka akan memiliki risiko tinggi terpapar Covid-19 (Banjanahor, 2021). 


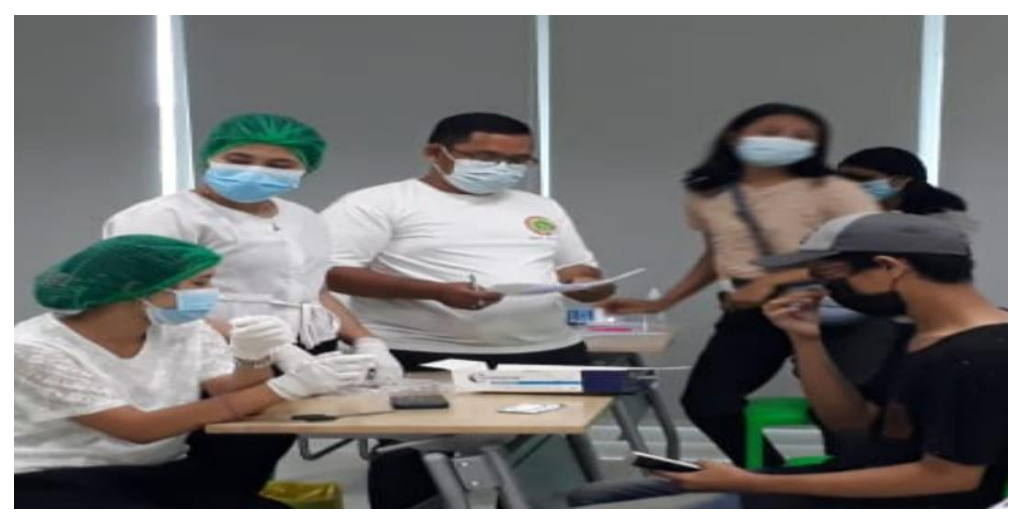

Gambar 2. Tahap Skrinning

Tahap tes swab atau rapid test banyak dipilih untuk mendeteksi dini virus corona Covid19 dalam tubuh. Ada pun jenis rapid test yang bisa digunakan untuk deteksi Covid-19, yaitu rapid test antigen. Pelaksanaan rapid test antigen dilakukan dengan alat dan bahan yang baru, kemasan juga dipastikan tidak terbuka. Untuk memastikan kemasan dalam keadaan baik, pasien kami mempersilahkan untuk mengecek dan membuka kemasan agar pasien mengetahu bahwa alat yang digunakan adalah layak. Kebanyakan peserta swab baru mengetahui secara detail alatalat yang digunakan untuk rapid test. Dalam hal ini peserta menambah pengetahuan tentang parid test antigen. Hal ini diperkuat bahwa pengetahuan menjadi dasar dari tingkat peringatan tentang kesadaran diri terhadap kesehatan (Manurung, 2020).

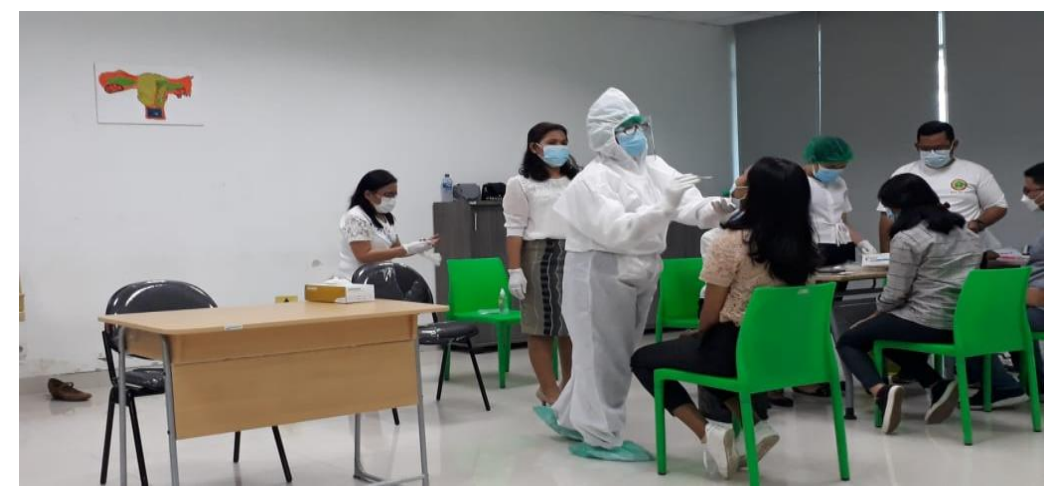

Gambar 3. Tahap Swab untuk Rapit Test Antigen

Pada tahap evaluasi atau menunggu hasilnya, kami dari petugas memberikan waktu kepada peserta untuk menunggu hasilnya di tempat yag sudah disediakan dengan mengatur jarak. Kami juga memberikan edukasi tentang jika ada keluarga atau peserta yang terkonfirmasi atau dicurigai terkena Covid-19. Kami juga memberikan layanan konseling secara individu kepeada peserta jika ada hal yang ini didiskusikan kepada petugas. Setelah itu ada 1 (satu) orang yang datang kepada petugas bahwa dia mengaku telah melakukan perjalanan ke suatu daerah tanpa dilakukan pemeriksaan rapid test Covid-19. Hal ini diperkuat konseling dapat memicu keterbukaan informasi serta dapat menimbulkan kecemasan kepada pasien (Silaen, 2019). 


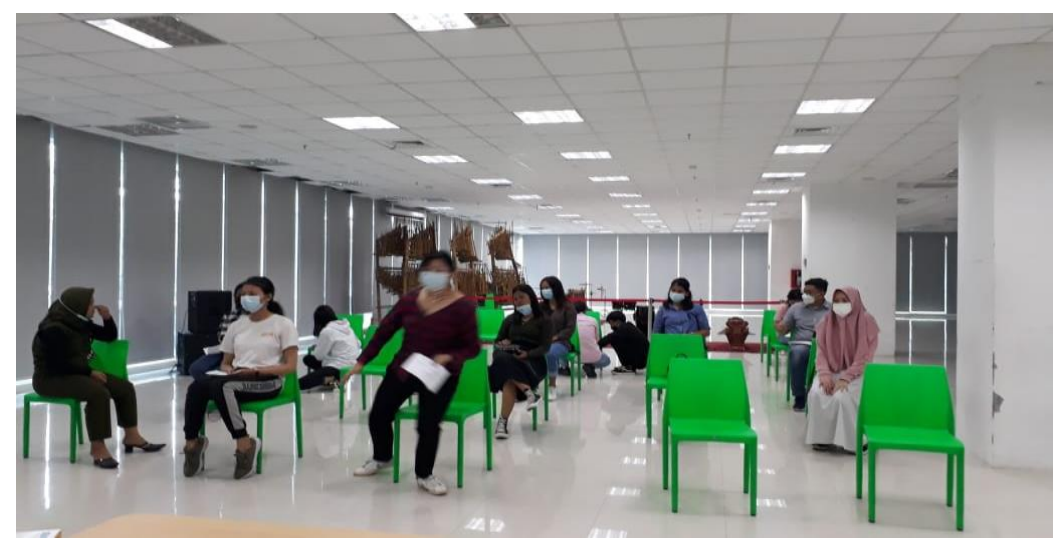

Gambar 4. Tahap Evaluasi post Swab

Pada tahap pemberitahuan hasil rapit test, maka peserta swab akan dilakukan konseling terhadap 1 (satu) orang tersebut, maka segera kami lakukan pemeriksaan/skrinning. Pada tahap skrinning peserta tidak menunjukkan gejala demam, batuk, flu dan hilang penciuman. Akan tetapi peserta baru selesai melakukan perjalanan masih 3 (tiga) hari sehingga belum spesifik menunjukkan gejala. Petugas juga langsung melakukan swab dengan menggunakan alat pelindung diri yang standar. Setelah dilakukan swab, maka kami menunggu hasilnya selama \pm 5 menit, maka hasilnya positif. Kami langsung melakukan konseling tepat dan terukur kepada di ruangan tersendiri. Kesimpilan dari konseling maka perlu dilakukan isolasi mandiri selama 14 hari, jika menunjukkan keadaan tubuh yang kurang stabil segera ke rumah sakit terdekat dengan menggunakan masker.

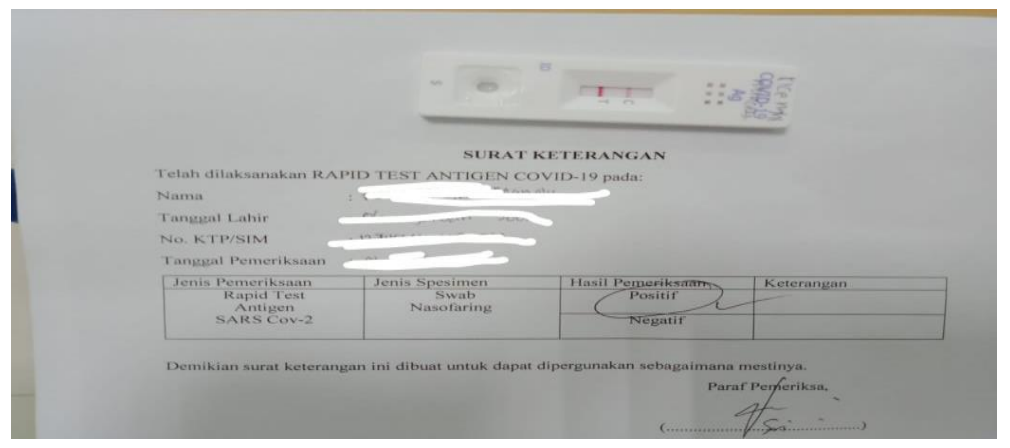

Gambar 5. Pemberitahuan Hasil Rapit Test

\section{KESIMPULAN}

Kesimpulan kegiatan ini bahwa telah dilakukan kegiatan Rapit Test Antigen kepada Panitia Generasi Muda Kota Medan dan Deli Serdang di Kampus Politeknik Wilmar Bisnis Indonesia selama 2 hari sebanyak 100 orang, hasilnya ditemukan 99 orang non reaktif (negatif) dan 1 orang reaktif (positif) terkonfirmasi covid-19 dengan rapit test antigen. Saran agar melakukan komunikasi dengan fasilitas kesehatan untuk melakukan rujukan testing swab PCR untuk menindaklanjuti hasil rapit test antigen. Kegiatan ini sangat bermanfaat guna untuk mendeteksi secara dini dalam pelaksanaan kegiatan/acara untuk menekan angka kejadian Covid-19. Harapannya semoga makin banyak Voluntary Tracing and Conseling Covid-19. Beberapa strategi yang disampaikan Gugus Tugas Percepatan Penanganan Covid-19 untuk menguatkan kebijakan physical distancing, tracing dan testing sebagai strategi dasar demi mengatasi penyebaran Covid-19 adalah penelusuran kontak (tracing) dari kasus positif. Melacak siapa saja yang pernah kontak dengan penderita bila dilakukan secara manual 
memerlukan waktu yang cukup lama dan dalam rentang waktu tersebut bisa saja sudah terjadi penyebaran virus yang sangat cepat.

\section{Ucapan Terima Kasih}

Kami mengucapkan terimakasih banyak ke berbagai Pihak dalam pelaksanaan kegiatan ini kepada Ketua Generasi Kota Medan dan Deli Serdang, Direktur Politeknik Wilmar Bisnis Indonesia dan Ketua LPPM STIKes Murni Teguh yang memberikan dukungan penuh terhadap pelaksanaan kegiatan pengabdian masyarakat oleh Dosen STIKes Murni Teguh terhadap masyarakat yang membutuhkan.

\section{Daftar Pustaka}

Afiana, F. N., Romadoni I., Yunita, Oktaviana, L. D., \& Hasanah, U. (2020). Pelatihan Teknis Penggunaan Aplikasi PeduliLindungi Guna Melacak Penyebaran Covid-19. Jurnal Pengabdian Mitra Masyarakat (JPMM) 2(2), 98-106. Diakses dari: https://ejournal.amikompurwokerto.ac.id/index.php/jpmm/article/view/999

Banjarnahor, S. (2021). Analysis of Covid Tranmission to Nurses in the Hospital. Al Insyirah International Scientific Conference on Health, Vol. 2. Diakses dari: https://jurnal.stikesalinsyirah.ac.id/index.php/aisch/article/view/1565

Kementrian Kesehatan. n.d. (2020). Situasi Terkini Perkembangan Coronavirus Disease (COVID-19).

Manurung, M. (2020). Pengetahuan Ibu Hamil Tentang Bahaya Merokok Terhadap Kehamilan Dan Janin. Jurnal Keperawatan Priority, 3(1), https://doi.org/10.34012/jukep.v3i1.800.

Rahardja, I. B., Dewi, D., Indriasari, Muslimat, A., Sukarman, Khoirudin, Rahdiana, N., Safril, El Adawiyah, S. D., \& Ramadhan, A. I. (2021). Pemanfaatan Daun Kering Sebagai Tempat Pembibitan Ikan Dengan Additive PVAc \& Resin. Abdi Moestopo: Jurnal Pengabdian Pada Masyarakat, 4(1), 1-5. https://doi.org/10.32509/am.v4i1.1111

Rohaniah, Y. \& Rahmaini. (2021). Sosialisasi Manajemen Keuangan Keluarga Pada Masa Pandemi Covid-19. Abdi Moestopo: Jurnal Pengabdian Pada Masyarakat 4(1), 45-49. https://doi.org/10.32509/am.v4i1.1371

Silaen, H. (2019). Pengaruh Pemberian Konseling Dengan Tingkat Kecemasan Pada Pasien Pemasangan Chemoport Yang Menjalani Kemoterapi Di Rumah Sakit Kota Medan. Jurnal Keperawatan Priority, 2(1), 86 - 92. Retrieved from http://jurnal.unprimdn.ac.id/index.php/jukep/article/view/390

Silaen, H. (2019). Pengaruh Pemberian Konseling Pada Pasien Hemodialisa Dengan Tingkat Kekambuhan Penyakit Hipertensi Di Rumah Sakit Kota Medan. Jurnal Keperawatan Priority, 2(2), 100 - 108. https://doi.org/10.34012/jukep.v2i2.573 